\title{
PROFESSORS, PRINCIPALS AND TEXTBOOKS FROM THE MIDWIFERY SCHOOL IN ZADAR
}

\author{
PROFESORI I DIREKTORI TE UDŽBENICI \\ PRIMALJSKE ŠKOLE U ZADRU
}

\author{
Jovan Maksimović", Marko Maksimović*
}

\begin{abstract}
SUMMARY
Midwifery in Dalmatia was highly undeveloped at the beginning of the XIX century. The health report from 1813 suggested that there were only 48 midwives in the whole province, and none of them with a degree from the midwifery school. After abolishing the Central Schools ("Ecoles Centrales"), which were founded at the time of French reign, and which had the university range, the professors who stayed in Zadar continued their work and teaching in the Midwifery School, which was founded in 1820 according to the decision made by Emperor Franz I, and started working in $\mathrm{I} 82 \mathrm{I}$.

Since the school was working continuously for the whole century, a lot of professors and principals passed through. Protomedicus of Dalmatia officially performed the duty of principals of the Midwifery School. Their life and work biographies were gathered in this paper.

Although the newcomers were mostly illiterate, very contemporary and valuable textbooks were used at that time. The professors of this school wrote some of these textbooks. This paper analyses those textbooks from the current medical science and praxis point of view, which points out to its significance and contribution of its authors to the reputation that the School enjoyed at that time.
\end{abstract}

Key words: Zadar; Dalmatia; Midwifery School; textbooks.

Scientific Society for the History of Health Culture of Vojvodina, Section for History of Medicine of Serbian Physician Society, Medical Faculty of Novi Sad, Novi Sad, Serbia.

Correspondence address: Jovan Maksimović, Glavna 210, 22400 Ruma, Republika Srbija. E-mail:maksimovic_jovan@yahoo.com. 


\section{INTRODUCTION}

The city status, as an administrative, political and cultural centre of Dalmatia during almost all periods of its existence, played the key role in the development of health and schooling in Zadar, mainly during the time of short French reign (1806-1813). The General Governor from 1806 until I8ı was Vincenzo Dandolo, a chemist and pharmacist born in Venice, who conducted scientific research, and was a member of many science academies in Europe. He was also active in politics and dazzled everybody with the ideas of the French Revolution. As soon as he came to Zadar, he established Weekly, publishing the first bilingual newspaper, in which one half of the page was published in Italian and the other half in Croatian („Il Regio Dalmata Kraglski Dalmatin"). The most significant merit of the French authorities, and especially of the governor Dandolo, was his effort to improve schooling in Dalmatia. Among other things, he signed the Decree about founding Licej in Zadar for schooling the lower range surgeons, obstetricians and pharmacists, and when Dalmatia was added to Ilyric provinces, Licej was declared the Central Schools („Ecoles Centrales") in the range of university, for the education of medical doctors and surgeons. When the Central School in Zadar was abolished in I8II, some professors took over classes of obstetrics in the newly established Midwifery School (I-4).

Childbirths in Dalmatia were done in houses with the assistance of skilled women, who people called "babice" ("levatrice“ in Italian), and in the countryside they were called "baba namirna“, if they were part of a family, and "baba izvanjska“, if they were not one of a family members, including both sides of the family. When childbirth got complicated, midwives called city surgeons, physicians, or masters of childbirth. Midwives were not educated back then, and their knowledge was passed on from a mother to a daughter and from daughters in law to mothers in law. That is why, in the list of health workers from I8I3 made by French health authorities, it was written that there were 48 midwives in the province and none of them had a degree in midwifery. In the February I8I8 report of Dr Andrija Mosetig, the Dalmatian protomedicus named by Austrian Health Authorities, stays, that there was only one educated midwife in the whole Dalmatia, namely in Kotor (5-10). The death rate of mothers and babies was very high due to these reasons. Therefore, Dr Andria Mosetig had the initiative to establish the Midwifery School in Zadar. The decision about establishing the "Teaching facility for theoretical and practical midwifery" was signed by the Emperor Franz I on the $31^{\text {st }}$ of October 1820 , and the school started working in the Civilian Hospital 
in Zadar at the end of the year 1821. At first, classes lasted for two semesters. After each semester, student had to pass a public exam and at the end of the school year the "strict exam” („rigorozo"), after which they got a degree. Classes were held in Italian and Croatian ("Illyric") language, and every year approximately twelve female students finished their studies. Obstetrics was the only subject that was taught in the Zadar's school and all other midwifery schools at the very beginning. The

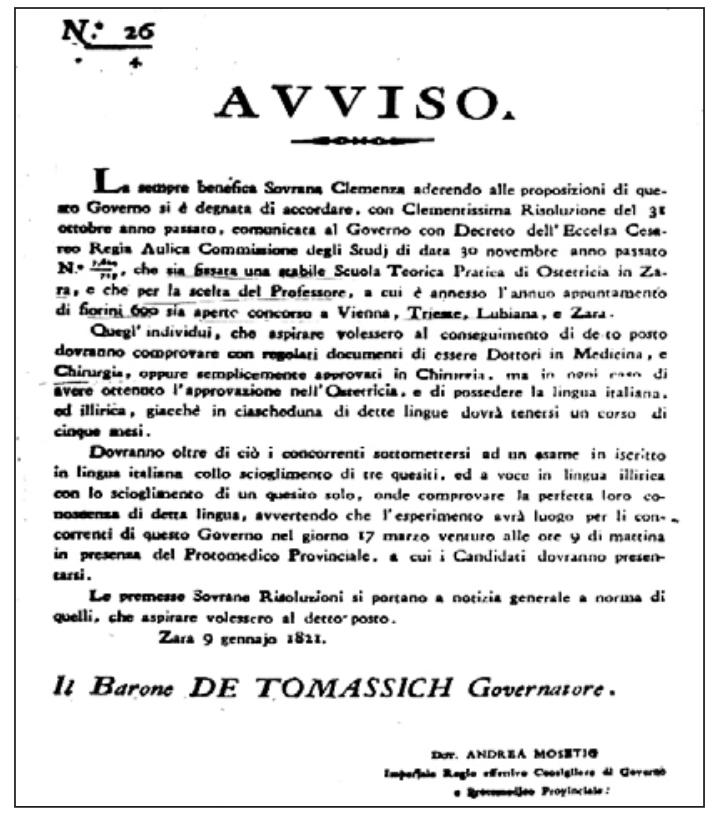

Figure I. Notification about the opening of the Midwifery School and the contest for a professor position (DAZD).

following documents were necessary to collect in order to sign in for classes: I. Birth certificate 2. Marriage certificate if married, or Death certificate if widowed 3. Testimonial about good behaviour issued by local vicar and approved by municipal administration 4. Health assurance 5. Vaccination records 6 . Poverty assurance, also issued by local vicar and approved by municipal authorities for those students who wanted the scholarship. Although the Rule Book of the Zadar Midwifery School implied that students had to know to read and write, reports said that a long time more than a half of them were illiterate (II-I4).

At first, the professors of obstetrics were hired by applying to a contest. It is not known how many candidates applied for the position of the first professor, since there is no data about that, but it is certain that Giuseppe Dall'Oro was elected first, so it can be considered that he was the most capable and privileged from the authorities, so neither of the candidates rose to the occasion. However, besides Dr Andria Mosetig, mr. chir. Giuseppe Dall'Oro was actively involved in the founding of the school. For the next contest, announced on the $26^{\text {th }}$ of April I827, the three candidates entered. They should have passed written and oral exam in front of the panel, and to the following 
contest, on the $\mathrm{II}^{\text {th }}$ of April $\mathrm{I} 832$, five candidates applied. The interested candidates had to confirm regularly that they were actual doctors of medicine and surgeons, or only questioned surgeons, who should pass the obstetrics exam yet, and they had to know Italian and Illyrian. The contest was opened in Vienna, Ljubljana, Trieste and Zadar at the same time. Applicants had to pass a written exam in Italian and an oral exam in Illyrian, which implied answering the 3 questions: $\mathrm{I}$. What needs to be said about parts necessary for the nutrition and survival of zygote in the uterus, 2. What are the causes of uterus rupture, which are the symptoms for recognizing it, and what needs to be done in such a case, and 3. In which cases caesarean section needs to be done and how is it done? The question in the oral exam was: "Which phenomena are linked to the natural and easy childbirth?" Dr Weber, the protomedicus at that time, gave the thorough report about this exam in the name of the panel. The advantage was given to Dr Petar Marinković. However, with the Emperor's decision on the $19^{\text {th }}$ of February 1934, due to the unknown reasons, for the professor of obstetrics was named $\mathrm{mr}$ chir. et opst. Ante Kuzmanić, the second best, whose work was very appreciated by the panel. Nine candidates applied to the contest announced in 1854 . This time they did not have to pass the exam, but, according to the submitted documents and already shown capabilities, the most capable candidate was suggested for the professor of obstetrics to the authorities in Vienna. In this case, it was Domenico Marcocchia from Split, a private contractual physician (medico condotto) in Obrovac.

Obligations of the obstetrics professor, according to the Rule Book of the Midwifery School, are to make a selection between female candidates who applied, to teach classes on certain days and at a certain time, to test students' knowledge once a week, to be an interrogator on semester and strict exams, and to inform the principal by writing the regular reports. Also, he had to take care of health of mothers and newborns, regularly visit the maternity ward, determine the therapy and nutrition of the patients, and permanently stay alert if his assistance was needed in complicated cases, and in case of his absence to inform the director and find himself a substitute. Besides that, he had to take care of the order and cleanliness in the maternity ward and school, and of the economy issues at the Institute, in which case he was getting help from priora, the chief midwife at the Institute. Furthermore, the chief midwife (priora) had to be involved in practical training of future midwives. In the end, there was a text of the oath that each new-assigned professor had to take. The oath implied the obedience to the Austrian Emperor, 
sticking to the rules when performing his duty, during which he will especially make an effort to inspire young students to respect the spirit of medicine in their future work, to break their bad habits, and spread the moral by setting his own example in the school and outside of it, also implying that he will treat them strictly professionally during exams and evaluation. This Rule Book („Rigolamento provisorio per la scuola d'ostetricia in Zara”), which regulated the behaviour of students, priora, professor, even the principal himself, as well as the other stuff, was put together by the protomedicus and the principal of the Midwifery School, Dr Aleksandar Drčić, following the example of other similar institutions in the country (I5-I8).

The last professor from this period of the Zadar Midwifery School was Dr Ante vitez Stermić. The Italians definitely closed the school in I9I8, after the occupation of Zadar at the end of the World War I and the fall of the AustroHungarian Monarchy, after 97 years of continuous work.

When Zadar was finally free of Italians and associated to the Socialist Republic of Yugoslavia, the School was reopened in 1948 in the leadership of prim. dr. Radoslav Akerman (I9-2I).

\section{THE PROFESSORS OF THE ZADAR MIDWIFERY SCHOOL}

until the end of the World War I, the Midwifery School in Zadar existed for almost a century, and to professors of obstetrics changed. Some of them were very important in obstetrics, as well as in health and general culture of Zadar and whole Dalmatia. The professors of the Midwifery School desk in chronological order:

r. Dr chir. Giuseppe (Josip) Dall'Oro $\mathrm{I} 82 \mathrm{I}-\mathrm{I} 827$

2. Mr chir. et opstet. Marko Hajtilović I $827-1831$

3. Mr chir. Giuseppe (Josip) Bernt I $83 \mathrm{I}-\mathrm{I} 834$

4. Mr chir. et opstet. Ante Kuzmanić

$1834-1854$

5. Dr Francesco (Frano) Danilo $1854-1855$

6. Dr Domenico Marcocchia $\mathrm{I} 855$ - I 880

7. Dr Vinko Zanella

$1880-1902$

8. Dr Filip Colombani - as a suplent

$1902-1903$

9. Dr Nikola barun Lalich (Lalić)

1903- I912

Io. Dr Ante vitez Stermich (Stermić)

I9I2 - I9I8 
Dr chir. Giuseppe (Josip) Dall'Oro - or Dell'Oro, since he signed his documents in both ways, was the first professor of the Zadar Midwifery School. He was involved in founding the school, alongside Dr Andria Mosetig. He was born in Pavia in 1783 , where he graduated in surgery and obstetrics in 1806 , and afterwards he worked as a surgeon in Dubrovnik and Zadar. General Governor of Dalmatia, Vincenzo Dandolo, named him a professor of anatomy and surgery on Licej Zadar in 1807 , with the annual income of 3000 Venetian Liras and free furnished apartment. In 1808 , he became the obstetrics professor on Licej, and when Licej was raised to the Central Schools in the range of a university, Dall'Oro maintained his function until I8II, when it was called off, so he stayed in Zadar as the head surgeon of the hospital. In 1815, he stood out during the suppression of plague epidemic in Makarska, after which he got many public awards, and as the biggest recognition, the Gold Medal of Honour, assigned by the King personally. He died in Zadar on the $05^{\text {th }}$ of January 1827 ( $\left.12,19,22\right)$.

$\mathrm{Mr}$ chir. et obstet. Marko Hajtilovic - was the second professor in a row and the chief of the desk at the Zadar Midwifery School. He was born in Dubrovnik, and before he got to a professor, he was a surgeon in his hometown (,maestro in chirurgia ed opstetricia"). In the contest for the professor position in 1827 he applied alongside two more candidates, although he already worked at the School as an assistant professor ("professore provisorio"), and was a very capable one. However, the panel thought that he was too young for such a serious duty, being 24 years old, so Dr Petar Marinković was given the advantage for this position. Since he did not accept that duty, Marko Hajtilović was named for the position of a full professor. He stayed there until the $2 \mathrm{I}^{\text {st }}$ of December $\mathrm{I} 83 \mathrm{I}$, when he was replaced by an assistant professor, Josip Bernt (II,19,21,23,24,27).

Mr chir. Josip (Giuseppe) Bernt - a municipal and hospital surgeon in Zadar, had worked as an assistant professor in the Zadar Midwifery School, until the position of full professor took mr chir. Ante Kuzmanić. On the $\mathrm{II}^{\text {th }}$ of April 1832 was the contest for the full time professor, where he applied as an assistant professor. However, the panel gave him only the third place. Dr Petar Marinković took the first one, but he did not take the duty for the second time in a row, since the Royal decision made mr chir. Ante Kuzmanić the chief of the desk of theoretical and practical obstetrics in the Midwifery School in Zadar after almost two years after the contest, and mr chir. Bernt was an assistant professor during that whole time. After Kuzmanić had taken the duty on the $27^{\text {th }}$ of September 1835 , Giuseppe Bernt got the surgeon 
position in Sabiončelo (Sabioncello) in Dubrovnik, which was decided by the government $(\mathrm{II}, 23,25,26)$.

$\mathrm{Mr}$ chir. et obstet. Ante Kuzmanić - was the fourth professor and the chief of the department in the Zadar Midwifery School, and the first one who spent there the entire 20 years. He is one of the most significant professors of the Zadar Midwifery School. The first and foremost as a professor of obstetrics and gynaecology, also known as a public and national worker, and reformer of Dalmatia, a writer and founder of scientific and literary magazines, a fighter for the vast usage of vernacular language, and a writer of the first textbook for midwives in Croatian.

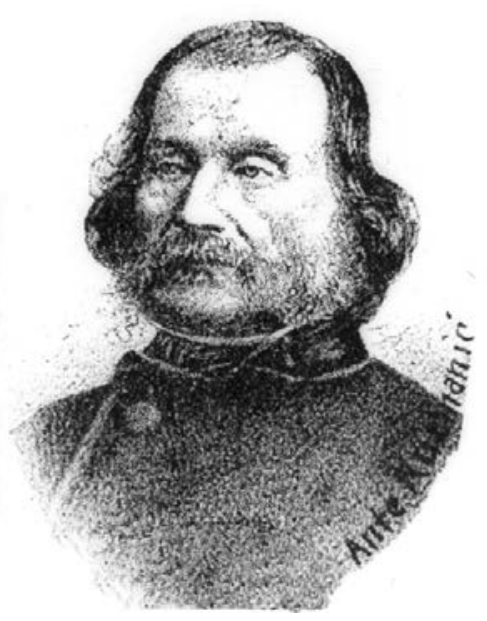

Figure 2. Mr chir. et obstet.

Ante Kuzmanić According to some data, he was born in Rogoznica in Omiš krajina, on the $2^{\text {nd }}$ of April 1807 (II $\left.23,25-27\right)$, while others think that it was actually in Lučac, a suburb in eastern Split, and that his parents originated from Rogoznica near Omiš (28). Regardless of his birth town, his family origin had the role in forming vernacular Dalmatian language with Ikavian dialect, for which he fought all his life.

He finished a secondary school in Zadar (Licej), studied medicine in Vienna, and after he had passed all the exams, he became the "master of healery and obstetrics". After he had performed his duty in Imotski and Opuzen as a kotar's surgeon, he was named a professor at the Panel of theoretical and practical obstetrics of the Zadar Midwifery School by the Royal board for schooling („La catedra di Ostetricia teoretica e pratica nell I.R. Istituto di Ostetricia in Zara"). For the next 20 years, he was performing his duty there and successfully trained many generations of midwives. He proved himself an excellent and talented obstetrician in 1832 when he was passing the exam for the position of the professor in the Midwifery School, where he gave very thorough answers, proved his knowledge in obstetrics, and showed a vast medical culture. The crown of his work is the midwifery textbook for the students of his school, which appeared in 1875 , nearly at the end of his lifespan, when he was already retired (29). 
Besides his medical vocation and education of midwives, Ante Kuzmanić used his intellectual knowledge to fight for the wide usage of Croatian language, proving that you can use it in literature as well as in the profession. That was not the case then, since Italian was the official and written language in Dalmatia, and scientific articles written in Croatian vernacular language with Dalmatian dialect, which was considered "common" and of the lower castes, were unimaginable. Ante Kuzmanić refuted this with his midwifery textbook, where he wrote all the medical terms in Croatian, not decreasing the scientific value or the seriousness of the book. By founding the first juristic magazine "Pravdonoša" in Croatian language in I851, he introduced the Croatian intelligence in Dalmatia, the way of using Croatian in the court, since Italian and German were used for those purposes until then. The people there, except the Italian minority, did not understand it. Therefore, Ante Kuzmanić was the first one who created Croatian juristic terminology in Dalmatia. Besides „Pravdonoša“, he also founded and edited other literal and political magazines, like "Zora dalmatinska“ and „Objavitelj dalmatinski”. He was also the editor of the Croatian „Smotritelj dalmatinski", since it was printed bilingually. He also tried out as a translator, and was one of the first physicians in our area who was engaged in the history of medicine. Among other stuff, he described the plague epidemic in Split in 1348 and wrote some articles on plague and famine in Dalmatia, and also the book dedicated to the family of the Split benefactors Ergovac, who were responsible for building the Split City Hospital (26,28,30-32).

Ante Kuzmanić, a professor and obstetrician, over time became more of a writer and founder of scientific and literal magazines, also the public worker and folk's revivalist. After 20 full years of working as a professor at the Midwifery School and an obstetrician in the hospital maternity ward, he retired and completely dedicated himself to his other vocation. He died in Zadar on the $10^{\text {th }}$ of December 1879 (33-37).

Dr Francesco (Frano) Danilo - led the desk for obstetrition as a probationary professor since 1854 , after Ante Kuzmanić had left, until the $18^{\text {th }}$ of February 1855, when Domenico Marcocchia took the professor's position.

He was Dalmatian, born in Kaštel Stari in $\mathrm{I} 8 \mathrm{r} 3$ who finished high school in Zadar, and medicine in Vienna in 1837 , after defending his thesis "De vi ventorum" ("The discussion about effect of wind on human health"). $\mathrm{He}$ was a kotar physician in Opuzen, Budva and Knin, and eventually in Zadar, where he also worked as the hospital's controller and probation professor 
in gymnasium. In addition, he was a member of the Matica dalmatinska, a correspondent member of the Society of Agronomy in Vienna "Ateneo", the Association for Science, Literature and the Arts in Bassano, and other literary and scientific societies. He was a president of Provincial Health Council and a consultant of the Regency in Zadar. He wore the Medal of the Iron Crown of III degree, and received the nobleman title in I876, so since then he signed as Frano the knight Danilo. As an interesting personality with great curiosity, he was also taking interest in herpetology (the branch of zoology that studies amphibians and lizards) and malacology (the branch of invertebrate zoology that studies molluscs). Therefore, he was very much responsible for arranging the Natural History Museum in Zadar. He is also known as a numismatist $(9, \mathrm{II}, 23,38)$.

Dr Domenico Marcocchia - was the professor of the Zadar Midwifery School for the full 25 years. He was assigned there by the Royal decree after the contest was pronounced, in spite of a large competition of nine candidates who had qualifications in surgery and obstetrics.

He originated from Split. Previously, he had the physician position in Obrovac and at the age of 45, was a father of five children. He studied surgery, obstetrics and epidemiology in Vienna. Only after a few years of surgical practice, he defended his dissertation at the Padua Medical Faculty in I850. In the dissertation "Alcuni cenni sull isola di Meleda“, he described Mljet, its population and the so-called "Mljet disease", very unusual and rare heritable skin disease with clinical manifestations of hyperkeratosis on one's extremities. Many scientists were exploring this particular disease, and modern examinations done by prof. dr. F. Kogoj and Dr Bošnjaković, mostly confirmed the conclusions to which Dr Marcocchia had come at his time. Dr Domenico Marcocchia was a surgery assistant in the Split Hospital, and then a contract physician in Šibenik, Vrlika and Obrovac. In I855 he successfully suppressed the cholera epidemic on the island of Rab, and as a professor in the Zadar Midwifery School, he advanced his classes, which he taught in three languages and contrary to his predecessors, twice a day - in the morning and in the afternoon $(9, \mathrm{II}, 2 \mathrm{I}, 23,38)$.

Dr Vinko Zanella - got the position of the professor at the Zadar Midwifery School in 1880 , and stayed there for 22 years, until he died in I9O2.

He was born in Vis in 1842 , graduated from the high school in Zadar and studied medicine in Padua, Vienna and Graz, where he graduated in medicine in 1872 . After that, he assisted there in the hospital for a few years. He 
got a degree in medicine, surgery, and a master degree in obstetrics and ophthalmology. During his studies in Vienna, he was a student of then famous doctors: Billroth, Škoda and Carl Braun von Fernwald, which had an impact on forming a character of a young doctor with modern and advanced medical attitude. His abilities surfaced when he performed a duty in Zadar. In I887 Zadar got a new hospital with the maternity ward ("maternica"-"maternite") with 12 beds, orphanotrophy, and a Midwifery School with boarding school for 9 to 12 female students. Dr Zanella arranged the maternity ward according to the contemporary principals, and advanced the classes in the school. He also introduced the so-called "repeated courses" for midwives who forgot about what they were previously learning. Although he did not write the textbook, he introduced to that school the most contemporary textbook at that time, by professor from the Midwifery School in Zagreb, Dr Antun Lobmayer.

When the school's principal protomedicus, Dr Augustin Ivanić, became the president of the country board ("Province government"), and the position of protomedicus and school's principal became empty, dr Zanella performed the duty of the principal of the Midwifery School from 1892 to 1898 . Besides that, according to the wish of every doctor, he was named a director of the hospital, so this was also his duty during that time. Dr Zanella was the professor of hygiene on the Small and Big Catholic Seminary, in the Orthodox Church and the Male monastery in Arbanasi territory. He stood out as a national worker and benefactor. In 1902, he suddenly died in Zadar. Dr Vinko Zanella was a founder of featured gynaecologists-obstetricians. His son, Dr Srećko Zanella, an assistant professor, was a famous gynaecologist from Zagreb, a longtime assistant professor, and the principal of the Zagreb Midwifery School, and his grandson prim. dr. Davor Zanella was a famous gynaecologist in the „Dr Kajfeš” hospital in Zagreb (II,I4).

Dr Filip Colombani - a secondary doctor and assistant in the hospital and maternity ward in the Dr Vinko Zanella time. After Zanella had died, in the period between 1902 and 1903 , he temporarily ran the school and maternity ward. However, when Dr Nikola Lalić took that place, Dr Colombani moved to Sibenik. First, he was primarius of the surgical department and later, the director of the hospital in Šibenik (II,22,23).

Dr Nikola barun Lalic (Lalich) - is one of the most important professors of the Zadar Midwifery School, not only as a professor and obstetrician, but also as an important person in the history of Dalmatian's medical culture. 
In the hospital in Šibenik, he managed to create the first contemporary surgical department. Occasionally visiting clinics in Vienna and Rome, he adopted innovations of operative medicine, especially from the abdominal surgery.

Dr Nikola Lalić was born in Knin in I862. He finished the secondary school in Zadar and got a degree of a medical faculty in Vienna in 1855 . Between 1886 and 1889 , he worked as a community medical doctor in Blato (on Korčula Island) and Zlarin (on Zlarin Island). In ı889, he started working as a doctor at the hospital in Šibenik, and in the same year, he became primarius of the hos-

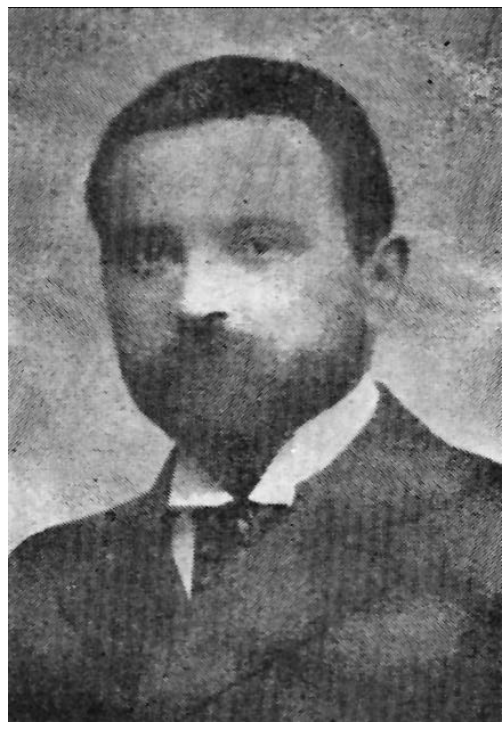

Figure 3. Dr Nikola Lalić pital and its expert and administrative manager. At that position, he stayed for $\mathrm{I}_{3}$ long years, until he came to Zadar in 1903. That was the most significant and prolific period in his life.

When we talk about the time when he worked in Šibenik, it is impossible to divide it from the life and work of Dr Božo Peričić and vice versa. Their biographer S. Sirovica says that they remarkably complemented each other in their work. Dr Božo Peričić came to the hospital in Šibenik at the same year as Lalić, but a little far behind, so as a second in a row and younger than Lalić, he stayed there as a secondary physician of the hospital, while Lalić was the primarius. That did not prevent them from building a great friendship, professionally and privately. Their work cannot be separated or assigned more to one than to another. They complemented each other and the results that came out, could be summarized like this: $\mathrm{I}$. In the field of general surgery they managed to advance and modernize its organization, and also to introduce new operational methods. 2. They gave their contribution to solving the problem of the sickness called „škrljevo“. 3 . They dealt with the problem of echinococcus in the pathology of Dalmatia and published their observations. 4 . They were the first to publicise the reports about the work of the hospital $(\mathrm{r} 4,2 \mathrm{I}, 39,4 \mathrm{O})$.

In the year 1897 Dr Nikola Lalić reached the zenith of his fame. When his friend and an associate Dr Božo Peričić left Šibenik in order to take place 
of primarius in Zadar Hospital, and when his beloved wife died, brought Dr Lalić a great psychological stress that he could not overcome for a long time. Emotionally weak and shaken, he thought of leaving Šibenik. He succeeded after five long years, when he took the position of a professor in the Zadar Midwifery School. Dr Filip Colombani from Zadar took his place in Šibenik.

The second period of work and life of Dr Lalić started with his transfer to Zadar. In the new environment, he dedicated himself to organizing and improving schooling in the Midwifery School, so in 1903 he ordered some teaching aids. Besides that, he was involved in publicating, so a few publications, newspaper articles, and a midwifery textbook originated from this period. In the same year he published the brochure "The importance of midwife", where he critically presented the organization of midwife's field of service in Dalmatia. In 1906, he translated in Italian and published in Vienna the third edition of the famous midwifery textbook by prof. dr. Ludwig Piskaček, while in 1908 he published his own "Book for midwives". However, it appears that after seven years of successful work on a position of professor in the school and primarius on the maternity ward, he again faced an emotional instability, which resulted in leaving Zadar and moving to Split in Igro, where he spent seven more years as a medical consultant. Dr Nikola baron Lalić died in Split in $1917(\mathrm{I} 4,41,42)$.

Dr Ante vitez Stermić (Stermich) - replaced Dr Nikola Lalić at the desk in the Midwifery School after Lalić went to Split. He was only a replacement for him at first, until in 1912 he was officially given that duty.

He was born in Zadar in 1863 and graduated in medicine in Vienna, where he specialized obstetrics and gynaecology, and worked as an assistant physician at the III Midwifery Clinic and School in Vienna, and at the II Midwifery Clinic in Vienna. After returning to Dalmatia, he worked as a kotar physician in Zadar, and replaced

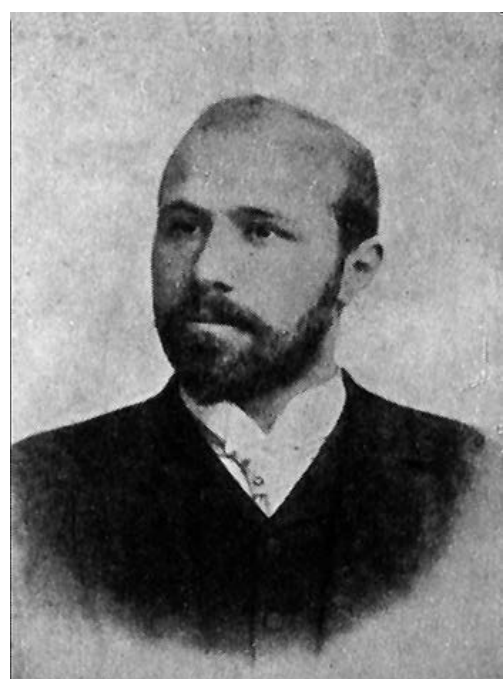

Figure 4. Dr Ante Stermić Professor Lalić. Even then, in Igrr he published the translation of the book by 
Vienna professor Ludwig Piskaček "Textbook for students in the midwifery school and manual for midwives" in Croatian.

According to data by M. Škarica, Dr Stermić was noble, very capable and fair, and he pleaded for better training of his students, who appreciated and loved him very much. Students at that time were literate, so he had an easier time accomplishing that. Praises and awards for being a good gynaecologist, he also got from his professor Dr Piskaček, who in his forewarn in Croatian edition of the textbook, expressed that the translation would be "perfect in any way", since during his stay in Vienna Dr Stermić gained profound specialist knowledge in midwifery, as well as the ability to teach midwives.

Last years of his life, he was sick a lot. Dr Ivo Marčelić, primarius and director of the hospital in Zadar then, replaced him in his work during that time. Dr Ante Stermić died on the $27^{\text {th }}$ of February 1920. He was the last in a row of professors at the Zadar Midwifery School during the first period of its existence, which covered one whole century (II,I4,23,43).

Pictures of professors, directors and book covers of the Midwifery School in Zadar are mostly published.

\section{PRINCIPALS OF THE ZADAR MIDWIFERY SCHOOL}

According to the regulations then, health adviser or protomedicus of Dalmatia, according to his duty also needed to be the principal of the Zadar Midwifery School.

Dr Andria Mosetig - was the country's health adviser and protomedicus of Dalmatia from I8I8 to 1827 . He was the first to realize the defeatingly bad condition of Dalmatian health at the beginning of the Igth century. This was especially obvious due to the great level of morbidity and mortality of mothers and newborns, so, since he wanted to help a "suffered population", he started the initiative for founding the midwifery school for whole Dalmatia, with a seat in Zadar. Regarding this, he presented to the authorities on the $2^{\text {nd }}$ of February I8I8 and the "Institute for schooling of theoretical and practical midwifery in Zadar", which was the official name of the School, started working on the $\mathrm{I}^{\text {st }}$ of October $182 \mathrm{I}$. The first official director was Dr Andria Mosetig. With inconclusive data, it can be assumed that he originated from Slovenia, from Roncian near Gorica, and from the files in Zadar archive, where it can be seen that he mastered German language, we can conclude that he graduated in medicine on some Austrian college. „Almanacco 
provinziale della Dalmazia" says, that from 1822 to 1826 he was the member of the Society for agriculture, art and sales in Gorizia, and he was honoured with the Great Gold Medal (it is not known for which credits). Why he left Zadar in 1827 is not clear, and $\mathrm{R}$. Jelić confirmed that later he was protomedicus in Milan, from where he was transferred to Moravska $(5,19,22,23,44)$.

Josip Asleksandar Drčić - was signing as Derchich. As a principal of the Midwifery School and protomedicus of Dalmatia, respecting regulations of other similar institutes in the country, he assembled "Temporary statute for the Zadar Midwifery School", where he established the organization fundamentals of life and work at this Institute, which was topical within years, with only a few made changes. He was born in Zagreb in 1798 , and graduated in Vienna in 1820 with the dissertation "Hygiene infantum et puberum". After finishing his studies, he was secondary physician in the hospital in Vienna, and after returning to homeland, he became the district physician in Dubrovnik. He imposed himself with energetic suppression of epidemics. He gave away free medications, and prevented "Mljet disease", an endemic for the Mljet Island, supressed one sheep epidemic that threaten to spread to people, and supressed the epidemic of unknown origin on the Šipan Island. The result of these successes was his assignment as a governship adviser and protomedicus of Dalmatia with seat in Zadar. His organizational skills surfaced. He was managing the hospitals and other health institutions in the area. With useful regulations, he saved lives of the majority in 1830 , when famine and infection diseases raved. Due to his exceptional organisational skills, he moved to Venice. As the protomedicus of the Republic of Venice he travelled, for scientific reasons, to the Austrian Monarchy, Galicia, Moravia and Silesia, all of which was described in his travel book. It was incredible how good he knew geology, mineralogy and botany. In 1837, he married Baroness Karolina Kübeck, and in the same year, he got the Austrian noble title by the King Ferdinand V, due to his merits in the field of public health. In his noble coat of arms, there is the Rod of Asclepius with the serpent that symbolizes the doctor's class, and his pronounced noblessy in Zagreb and Varaždin. He died in 1862 . $(19,22,23,38,45,46)$.

Dr Francesco (Franc) Weber - was the protomedicus of Dalmatia and the principal of the Midwifery School from I83I until I837. He originated from Slovenia and was a member of the Agricultural Society in Ljubljana. As a principal of the school, he was also the president of the Exam commission, when Ante Kuzmanić applied for the professor's position. He took Dr Bernt's side regarding the central government's critics about prolonged course, due 
to teaching in two languages. Dr Weber pledged for bilingual courses to proceed, since the female students were illiterate, so they were unable to use the obstetrics textbooks $(23,27,44)$.

Dr Vilim Menis (Gugliemo Menis) - performed the duty of protomedicus in Dalmatia from 1838 until 1853 . He originated from Udine, and graduated in medicine in Padua. He worked as a physician on the Krk Island, in Dubrovnik and Budva, where he actively participated in the Commission for the Defense of the Plague Epidemic. He was the state's adviser and a member of many academies. He presented Austria at the Medical congress in Toulon in 185 , where he debated about establishing quarantine and suppressing epidemics on the Mediterranean. He proved himself also in the literature. He wrote a book "Il mare Adriatico" and a poem „Hygiea de arte bene diuque vivendi“" (II,I9,23).

Dr Francesco (Frano) Petris - was a substitute for diseased Dr Menis on the position of protomedicus and a principal of the School since I853 until I858. He interceded for students for scholarships, since economic situation in the village was bad at that time, and families were without income and opportunity to send their daughters to the midwifery school. Dr Frano Petris stood out as a kotar physician while suppressing the cholera epidemic, which he suffered himself in 1863 (II).

Dr Nikola Pinelli - was a province's health adviser and the protomedicus of Dalmatia from 1858 to 1870 . He is one of the members of an eminent and numerous Zadar medical family Pinelli, which resulted in 8 doctors. Four of them were Dalmatian protomedics, two of them professors of the Medical and Surgery School in Zadar, and one of them a director of the hospital in Zadar.

Dr Nikola Pinelli, son of serdar (Ottoman rank) Petar, was born in Venice in 1802 , and graduated in medicine in Padua. In his dissertation he considered reasons why syphilis in newborns, accepted in maternity, should be diagnosed before given to

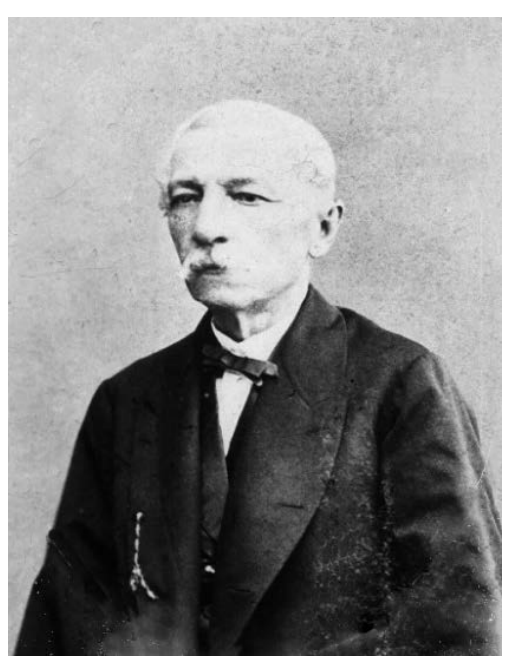

Figure 5. Dr Nicollo Pinelli, the principal of the Midwifery School in Zadar. 
breastfeeding, since this disease is transferred through milk to healthy children. Firstly, he was performing his duty in Kotor as city's, and in Dubrovnik and Budva as a district's physician. During his service in Dubrovnik, he was a doctor of the Bishop of Montenegro Petar Petrović Njegoš. Besides that, he supressed plague at the Albanian border and stood out by vaccination actions. During the cholera epidemics on Pag in 1855 , he gained big merits, when he guided the action as a district physician and got sick, then barely pulled out. Due to his dedication, the Emperor Franz I honoured him with the Knight's Cross in 1855 . He also did some experiments with so-called "animal magnetism" in Dubrovnik. Actually, it was some kind of hypnosis done on people in order to remove the pain during surgical procedures. He managed to amputate the right arm of one patient under such anaesthesia, about which the Zadar newspaper "Gazzetta di Zara" reported in 1847. Besides, he was a member of the Military Commission, a physician to the Harbour and Health Captaincy in Zadar, the president of the Permanent Doctor's Commission, a member of the Board for Military Wounded and the physician of the Jesuits in Zadar. He retired in 1870 and died in Zadar in 1872 from stomach cancer (II, I9, 23, 47, 48).

Dr Mihovil Milković - was the Dalmatian protomedicus from 1872 to 1879 , and the principal of the Zadar Midwifery School during the time when professor was Dr Domenico Marcocchia. He originated from Šibenik, and graduated in medicine in Padua in 1847 with very interesting dissertation from the field of dentistry, named "Sulla patologia e theoria dei denti“. He was the teacher of "healing and obstetrics" in Zadar. For a while, he was the director of the hospital. In addition, he was an important member of "Matica Dalmatinska" and a fighter for cultural arising of Dalmatian people (9, II, 23, 38).

Dr Karlo Neumayer - was the district's health reporter from I879 until 1883. He originated from Dubrovnik, and died in Zadar when he was 52 (5).

Dr Gustav Ivanić (Augustino Ivanich) - was the district's health reporter and the principal of the Midwifery School at time when Dr Vinko Zanella and Dr Filip Colombani were professors. His family originates from Slovakia, while Augustin was born in Šibenik. He worked as a physician in Obrovac, and after that, for many years in Zadar. He was much involved in politics, and was a MP for Zadar's Italian landowners in the Dalmatian Parliament and the Royal Council in Vienna. He stood up for building hospitals in Zadar and entire Dalmatia. When he became the president of District's Government, 
the position of principal at the Midwifery School was empty, so Dr Zanella performed that duty in his absence. Dr Ivanić established "Doctor's assembly of Zadar city". He died in Zadar in 1902 ( 5, II, 23, 25, 49).

Dr Jakov Givanović - was the district's health reporter and the principal of the Midwifery School from 1902 to I912. Besides that, he was the Royal's adviser and the president of the Emperor's royal district council. He particularly stood out during the Herzegovina Uprising (I875-1878), when he devotedly and freely cured refugees from Herzegovina.

Dr Gjivanović was born in Dubrovnik in 1840, finished medicine in Vienna, and worked as a physician in Blato (Korčula), Dubrovnik and Kotor. He was involved in suppression of malaria with Dr Battara and led the first action of curing with kinin in Dalmatia. He also wrote medical debates "About circular diseases", "Ship's hygiene" and "Health report of Dalmatia from 1903 until 1905". He died in Zadar in 1912 (5, 7, II, 23, 25, 50).

Dr Dragutin (Karlo) Vipauc - was a district's health advisor and the principal of the Midwifery School from 1912 until 1918. He was born in Zagreb in I85I, went to the high school in Rijeka, and finished it in Graz, where he also graduated in medicine in 1875 . Firstly, he was community doctor in Ston, and then kotar's doctor in Sinj and Korčula. He particularly stood out as a young doctor during cholera suppression in Metković in 1886 and variola epidemic in Šibenik in 1887, which took 340 lives from February to December, and from which he also suffered. As a sign of recognition the municipal of Šibenik named him an honoured citizen, and the Emperor Franz Joseph gave him the highest Austro-Hungarian honour, a Medal with the golden cross and crown. In 1889, he got a position of kotar's doctor of medicine in Zadar, and since I912, he was the last protomedicus from Dalmatia at the time of the Austro-Hungarian Monarchy. In 1950, he died in Novi Vinodolski at the age of $99(5,23,5 \mathrm{I})$.

Dr Emil Petz - was the district's health reporter during Italian occupation of Zadar from rgig to 1941. He came to Zadar from Metković in 1903, and died in Zadar in 1942 (5).

\section{MIDWIFERY TEXTBOOKS FROM THE ZADAR MIDWIFERY SCHOOL}

Since the end of the i8th century and the beginning of the rgth century, the kotar's and count's physicians, who were using midwifery textbooks from the First Vienna Medical School (Steidelle, Lederer, Siebold), the 
Second Vienna Medical School (Späth, Piskaček), as well as the popular "Manuale di ostetricia teorica e pratica per le alunne levatrici" by Dr Rudolf Lamprecht, the professor at the University in Padua, trained midwives in short-term courses in Dalmatia (52).

I. ANTE KUZMANIĆ: Šestdeset učenjah iz primaljstva za primalje( Sixty lessons in midwifery for midwives), in Zadar by Špiro Artale, in Zagreb by Albrecht and Fiedler, in Pančevo by brothers Jovanović, 1875.

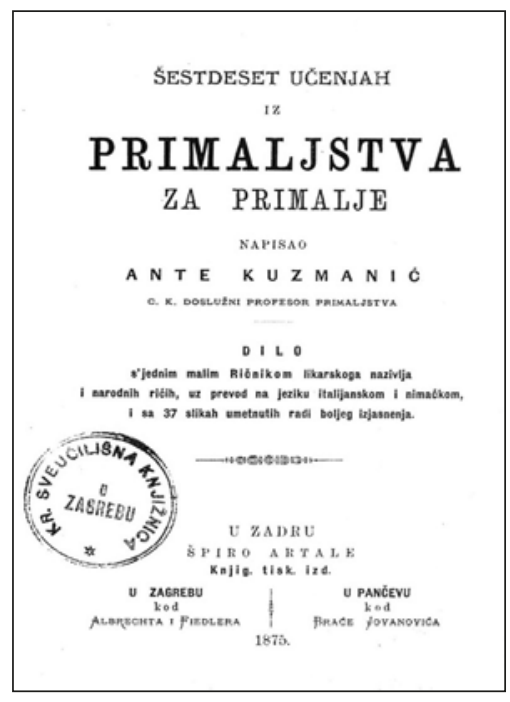

Figure 6. Midwifery textbook by mr chir. Ante Kuzmanić, a professor of the Midwifery

School in Zadar.
The first Midwifery textbook of Zadar's Midwifery was published in 1875 , meaning 50 years after the School's foundation and 20 years after the professor Kuzmanić stopped working and was retired. It can be assumed with great certainty that at that time the great need for that kind of textbook in the vernacular language was born, since midwives were rarely literate in order to use it.

His textbook was conceived in thesis („učenja“), in order for students and midwives to accomplish easier managing and gathering the useful information. He was using medical terminology in the vernacular language in CroatianDalmatian dialect, while the textbook

did not lose its scholarship. Professor Kuzmanić was actively involved in folk's enlightenment and endeavour to introduce vernacular terminology in court and medical praxis, therefore he put vernacular dictionary at the end of his textbook with translations in Italian and German. It was one of the first dictionaries of that kind in the Croatian spoken area and it presents the foundations of Croatian medical terminology. In order to point out to language specificity of his work, he started out his textbook maybe a bit too confidently with the next words: "Since Adam originated on Earth this is the first book of this kind". The book was printed in Zadar and was dedicated to then's protomedicus and the principal of the Midwifery School Dr Mihovil Milković. Very interesting data is that a few copies were printed in Zagreb and even in Pančevo with Jovanović brothers. 
The first lesson is dedicated to general terms, such as the definition of midwifery, then physical, character and moral features, that one midwife should have, and boundaries to which it is permitted for her to intervene. From the second to the fifth lesson, he spoke about anatomy and in the sixth about menstrual period and its significance in different periods of woman's life. Next six lessons are dedicated to normal pregnancy. When spoken about multiple pregnancies, he believes that it can be created with so-called "superfecundation". It is obvious that he was not informed about biology of conception, or the mechanism of stagnation of intrauterine growth of one of the twins.

The lesson about examination of a pregnant woman is divided properly into the external and internal examination, and a lot is said about auscultation of baby's heartbeat. Internal obstetric's examination, according to the text from the book, is done in the back-lying position of a woman, with one or two fingers of the right hand oiled or buttered for easier entrance to her vagina, and also for midwife's protection from the infection. Disinfection of midwife's hands before the internal exam, for the prevention of the labour tract infection, is not yet to be seen in Professor Ante Kuzmanićs textbook.

When teaching about miscarriage, the spontaneous and artificial were mentioned, there is a warning that their therapy is exclusively under the jurisdiction of a physician, and before his arrival, the midwife's obligation is to apply all the haemostasis procedures besides instrumental ones. Those procedures consisted of: putting on cold wraps at the bottom abdomen, giving cold drinks and injection of cold water into a vagina and a rectum, in order for the uterus to contract. If all those procedures failed, the last attempt allowed to midwife was to put a so-called "midwife's plug", or a tampon made of hemp with certain fibres coated around it, whose aim was to tampon the bottom segment of the uterus by firmly putting it to the vagina, and temporary stopping the bleeding, until doctor could do the instrumental revision.

All twenty lessons are dedicated to a normal childbirth, puerperium, newborn child and breastfeeding. Regarding the time of a normal childbirth, Prof. Kuzmanićs evaluation is a wide period from one to 80 hours. Three labour periods are mentioned in the book, the role of the amniotic sac is correctly explained, and the birth mechanism in the occipital position is explained within details. Only the face position is explained out of deflection states, and within normal positions the abdomen position is mentioned as such. 
Special equipment and a procedure regarding the child births in domicile conditions is described, since at that time the majority of the labours were performed in the house of a mother. Professor Kuzmanić is a supporter of the backside labour position, discussing about being the most available to a midwife and the least tiring for a mother. It is insisted a lot on the protection of peritoneum during expulsion by placing the right arm properly and by guided pushes, as well as lubricating the peritoneum with olive oil to make it more elastic and softer. In the 3 rd phase of a labour, when it is certain that placenta is detached, it should be removed by pulling the umbilical cord, and when it is discussed about nourishing the mother, the author suggests lying in bed 8-Io days after the delivery, without leaving a house for 15 days.

Attitudes of Prof. Kuzmanić regarding a cause of "temporary neonatal death" after the delivery are in coherence with attitudes of medicine at that time to those pathological states. The term "drop" stands for the newborns with intracranial haemorrhage and they are in so-called blue asphyxia. The second group includes the more difficult damage of the newborns, in the state today known as "pale asphyxia". In the first case, it was intended to release a certain amount of blood by various manipulations through umbilical cord, while in the case of more difficult asphyxia, bleeding through umbilical cord should have been prevented and breeding functions should have been gained by certain stimulative procedures.

At the beginning of the lecture on pathological labours a warning to midwives that leading such deliveries belongs to the jurisdiction of physicians, but midwives are allowed to intervene when doctors are unavailable, under the condition that they can perform the procedures that involve bare hands and not instruments.

Author described taking the external measurements of the pelvis with the Baudelocque's pelvimeter, in the lessons on abnormal labours regarding the bone part of the small pelvis deformities, all in order to measure the degree of narrowness. The author also described the indirect digital measuring of coniugata diagonalis during the internal obstetrics' exam. For the absolutely narrowed pelvis, caesarean incision is predicted even with a dead newborn, which is considered "pernicious" for a woman. During the therapy of eclampsia states, the most significant technique was releasing the blood and putting leeches on the head, since the cause of the origin of those conditions, not without reason, was considered to be, so called " plethora of the brain". Last ten lessons were dedicated to hand procedures for which a midwife had 
the authorisation when medical doctor was unavailable. At the end of the book, "midwife's christening" was described, and every midwife was authorised for that in case of life-threatening situation during or immediately after the delivery of a newborn. The procedure added up to the next steps: if any part of an endangered baby was emerging out of the uterus, she would be required to sprinkle it with warm water and say the next words:" I am christening you in the name of the Father, the Son and the Holy Spirit, if you are alive!”

His book is considered the first midwifery textbook in Croatian by some, besides Lalangue's book, which the same ones believe that it was not meant for the students of midwifery schools but for the ignorant peasant women (II, 53, 54).

2. Compendio di OSTETRICIA per le allieve delle scuole di Ostetricia e REPERTORIO PER LE LEVATRICI del Dott. LODOVICO PISKATSCHEK I. R. Peofessore d'Ostetricia presso Istituto per le Levatrici in Viena, Prima traduzione italiana sulla terza edizione tedesca del Dott. NICOLO barone de LALLICH I. R. Professore d'Ostetricia presso l'Istituto per le Levatrici in Zara, ... VIENNA, Wilhelm Braumüller, editore, 1906.

Since Lamprecht and Kuzmanic's editions were obsolete in the second half of the rgth century, Dr Nikola Lalić started with translating the most popular midwifery textbook in Austria, by Dr Ludwig Piskaček, a professor of obstetrics at the Vienna Maternity Clinic. Professor Piskaček's book was used then in the Midwifery Schools in Vienna, Prague, Graz, Linz, Salzburg, Klagenfurt, Ljubljana, Brno, Lemberg, and Černovic, and Dr Lalić translated it into Italian for the schools in Trieste and Zadar, in order to unify the educations of midwives in all schools for midwives in Austria. Question that imposes is, why Dr Lalić did not translate this book into Croatian. The answer is

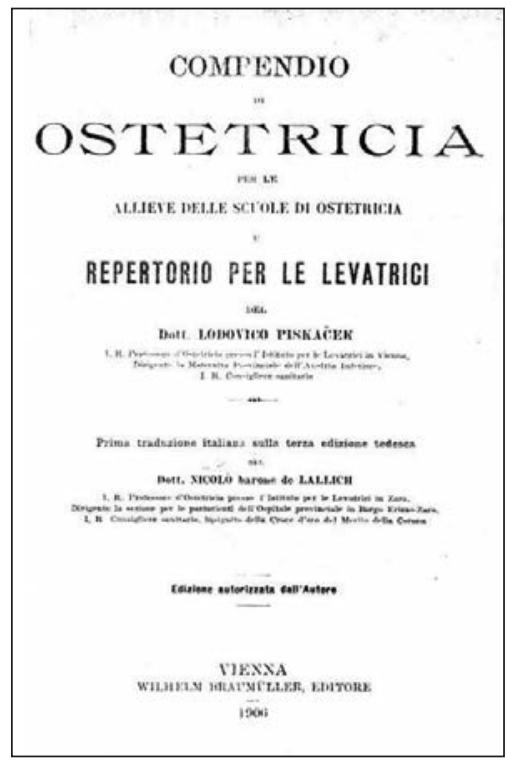

Figure 7. Lalić's translation of Piskaček's textbook in Italian. 
probably lying in the intention to publish his textbook in Croatian, whose preparations were in progress $(42,55)$.

3. KNJIGA ZA PRIMALJE, („Midwifery book") wrote by Prof. dr N. Bar LALICH, c.k. obstetrics professor at the Zadar Midwifery School, ZADAR, printed by Petar Janković, 1908.

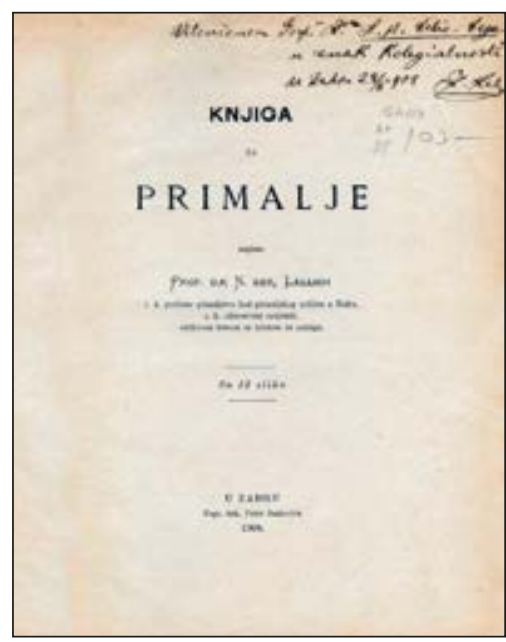

Figure 8. Dr Nikola Barun LalićMidwifery textbook.

After publishing the translation of Piskaček's textbook in Italian, Dr Nikola Lalić wrote and published his own textbook in Croatian intended for the students of Croatian and Serbian origin. While working on it, he was using other contemporary midwifery textbooks. Terminology was taken over from "Obstetrics" by Dr Antun Lobmayer from Zagreb and Dr Jovan J. Jovanović from Belgrade, but also, it is no wonder that a great influence of $\mathrm{Dr}$ Piskaček's textbook is noticed. Lalićs "Midwifery Book" was written in 120 pages with 12 images. It represents a real midwifery textbook without any thorough theoretical considerations.

Material is divided into I6 parts. The initial ones contain general terms about midwives, their vocation and instruments they should have, decontamination during labours, general anatomy, and anatomy and physiology of pelvis and women's genitals. Chapters 7 to II are about pregnancy, delivery and a child, and chapters 12 to 16 about pathology of it.

Besides all that, Dr Lalić considered that a midwife should possess the following features as well: the first and foremost to know how to read, write and calculate, not to be superstitious, to be strong and healthy, and particularly not about to faint. She should not be peculiar about smells, skin diseases, syphilis,"sučija" and other infectious diseases. He described within details the content of the "Midwifery suitcase", whose lid should be out of sheet metal, in order to serve for hand disinfection when needed, boiling the instruments and sterile water preparation.

Dr Lalić explained the principle of infection to semi-literal students in a simple way, which was very hard to understand at that time. In the same 
way the commitment and procedure of aseptic processes in life and work of a midwife was described, such as a ban to approach a healthy mother, if in the same day a midwife nourished someone with an infectious disease, especially "child delivery fever" or cancer, or if she in the same day worked around corpses. Before approaching to a healthy woman in labour, she had to take a bath, get changed and put on a clean white textile apron. She had to take care of her hands so they would not be covered with blisters, pustules or be wounded, and nails should have been deeply cut. Before every internal examination, she was obliged to wash her hands with warm water and soap, and then disinfected them with $2 \%$ solution of lysol and $\mathrm{i} \%$ solution of sublimate. In addition, she had to wash the genitals of a mother in delivery with water and soap, to smear it with lysol, and to boil the instruments in order to sterilise them.

In the chapter about "midwife's examination", it is particularly stressed out to search the medical history for data about possible rickets overcome, and during child delivery midwife can only burst the amnion sac exclusively with finger, not with an instrument in case of completely dilated cervix. During a child expulsion and perineum covering, prevailed position is side-lying position, since a woman cannot strain too much in that position, and a midwife is able to control the course of expulsion of a child and dilatation of perineum.

After a delivery, during puerperium, a midwife is required to visit a mother twice a day during 9 days, and later only ones a day, as long as there is a need for that. Mother is allowed to leave the bed only on roth day after a delivery.

In the part of the book that deals with the pathology of a pregnancy, delivery and puerperium, a particular attention is put on procedures in case of narrowed and irregular pelvis, as well as in cases of extensive haemorrhaging. Those procedures came down to temporarily taking care before the arrival of a doctor, and only in case when doctor was unreachable. A midwife could have intervened: she could have performed the combined twist and extract the baby by legs, tamponed a vagina with iodoform gauze if amnion sac was whole, or detached placenta by hands if the haemorrhage was extensive. In the chapter on irregular puerperium, the attention is put on the most dangerous disease of that time, "maternal fever" (,sepsis puerperalis“) $(55,56)$. 
4. Textbook for STUDENTS OF MIDWIFERY and manual for midwives, written by Dr LUDWIK PISKAČEK, translated by $d r$ ANTE vitez STERMICH, ZADAR, printed by Tiskara Schönfeld EO Co, IgII.

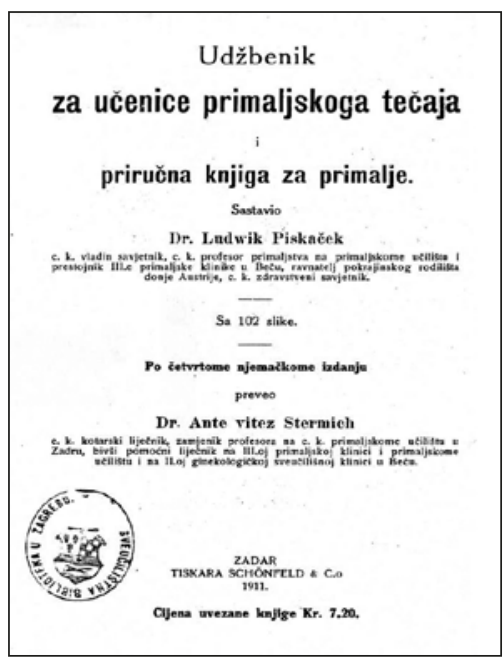

Figure 9. Stermić's translation of Piskaček's midwifery textbook in Croatian.

Dr Stermić translated the second German edition of the book written by his teacher prof. Piskaček at the time when he was assistant physician at the Third Midwifery Clinic (K.K. Midwifery School) in Vienna, but only the translation of the 4 th edition of this textbook was published in IgII, since Dr Stermić could not find a publisher before. Only when he took the position of the professor because of the absence of Dr Lalić, with the influence of his position, he gained financial resources and moral support for publishing this book. At that time, in order to uniform the training, Piskaček's book, as an official textbook for midwives, was introduced to K.K. Midwifery School in Vienna and every other Austrian school. It was more contemporary than any other textbook at the time, clearer, easier to learn from and with nice illustrations. Dr Božo Peričić, an author of the first Croatian medical dictionary, processed the terminology.

The material is divided into four big sections. The first section covers shortly basic anatomy, second one the anatomy of women's pelvis, and anatomy and physiology of women's genitals, and third the normal pregnancy, delivery, puerperium and nourishment of a new-born infant. The fourth section is dedicated to the pathology of the previous. In the wide introduction, as a supreme principal he stressed cleanliness of hands and instruments achieved by washing, cleaning and decontamination, so he listed the disinfectants used at that time: $2 \%$ lysol and cresol acid, hypermangan solution and sublimate. Sterilisation should have been done by boiling. Besides that, he described some terms regarding the preparation of solutions with different concentrations, measuring the length of a newborn, axillary and rectal measuring of body temperature, environmental temperature and temperature of the bath. Some sizes on a patient's body are compared to the sizes of a coin, palm, nut, apple, and kid's head, which is pointed out as a significant. 
As well as a spatial orientation on a woman's body (up to the head, down to the legs, in front to the frontal part of the body, and at the back to the back side) is important. The chapter about pelvis anatomy and woman's genitals is illustrated with precise drawings of topographic anatomy, some of which were taken over from textbooks by Späth, Schultze and Dickinson.

The biggest significance is dedicated to external obstetrics examination regarding the orientation of the baby in uterus, using so-called Leopold's Manoeuvres, as well as to the preparation of mothers for the internal examination, cleaning and decontaminating hands and instruments, and the external genitals of a mother in birth. Regarding a frequency of internal obstetric examinations, prof. Piskaček had the reasonably restrictive attitude, in order to prevent possible infections that can be carried in maternal paths and developing deadly puerperal sepsis.

The process of a labour was divided into three periods, the role of the labours (labour power), retraction and distraction part of the uterus, and the role of the amnion sac was interpreted. Left side position was recommended due to guarding the perineum during expulsion. The third labour period leading was restrictive. It was forbidden to retract the umbilical cord and tests for evaluating the detachment of placenta were described. Midwife was strictly forbidden to leave a woman after giving birth 3 hours after the placenta was delivered.

Labour pathology was correctly divided into diseases not related to pregnancy and diseases induced by pregnancy. A great significance was given to indirect digital measuring of coniugata vera through coniugata diagonalis. In cases of haemorrhaging due to spontaneous abortion and placenta praevia, mothers should have been given cold beverages and rinse with I\% lysol solution, and if needed, tamponading a vagina until the arrival of a medical doctor. In case of postpartum uterine atony, a midwife should have massaged the bottom of the uterus through abdomen and rinsed a vagina with boiled and warmed water to $45^{\circ} \mathrm{C}$, in order to induce uterus contractions. In the most serious cases of blood loss, in order to compensate the lost fluid volume, they should have been given the warm enemas with table salt. As one of the signs of foetal distress was the "meconium liquor "with foetus in the head position, and the presence of it in one of the first midwifery textbooks was not been interpreted as being connected to bowel motorics like in modern pathophysiology, but to atony, or with so called "paralysis of anal sphincter". 
Prof. Piskaček's book is one of the first midwifery textbooks, which, aside from illustrations, has the original images (II, 43, 55).

\section{Conclusion}

The Zadar Midwifery School, which had been founded by the Decision of Emperor Franz I on the $3 \mathrm{I}^{\text {st }}$ of October $\mathrm{I} 820$, and year after started to work, was the first school for midwives in Croatia with classes held only in Croatian language.

Dalmatia had medical and obstetric tradition since the ancient times, and as Dalmatian cities managed to save its autonomy during centuries, it allowed them to maintain culture of living, education, and health culture. The short French rule enabled them even greater success. In addition, in Zadar were founded the Central Schools, "Ecoles Centrales", in the rank of university with several faculties, including the Faculty of Medicine. After the French had left, the faculties were abolished, while the professors stayed. Some of them continued their work in the newly founded Midwifery School.

The initiative for founding the Midwifery School in Zadar came from protomedicus of Dalmatia Dr Andria Mosetic. The first professor of obstetrics was Dr chir. Giuseppe Dall'Oro, a Zadar hospital surgeon, and former professor of anatomy, surgery and obstetrics at "Ecoles Centrales". The school had one professor who taught obstetrics, and directors were, by official duty, protomedicus of Dalmatia.

From I82I to 1918 , ten professors and twelve directors changed while the Zadar Midwifery School was constantly working. Among outstanding professors was Mr chir. et opstet. Ante Kuzmanic, a writer of the first Dalmatian midwifery book, a protagonist of using Croatian language in profession and literature, an editor of many literature, political and patriot magazines, and a national revivalist. There were also Dr Vinko Zanela, who organized Zadar delivery department, and improved classes in the Midwifery School using modern principles, and Dr Nikola Barun Lalich, a founder of the modern surgery in Dalmatia and a writer of the book "The book for midwives".

As professors of Zadar Midwifery School were actually students of the famous Vienna Obstetric School, they wrote their books by modelling the books of their professors, and the classes in the Zadar Midwifery School were held according to the Vienna Obstetric School program. 


\section{REFERENCES}

1. Grmek M.D.: Les conditions sanitaires et la medicine en Dalmatie sous Napoleon I-er (1806-1813), Biologie medicale, N. „Hors-serie“, Paris, 1964.

2. Maštrović Lj.: Povjesni pregled školstva u Zadru, „Zadar-zbornik“, Matica hrvatska, Zagreb, 1964.

3. Grmek M.D.: Medicinsko-kirurška škola u Zadru 1806 -1811., Jugoslavenska akademija znanosti i umjetnosti, Zagreb, 1961.

4. Melik V.: Ilirske provincije u našoj historiji, Zbornik skrajšanih referatov XXX sastanka Zveze znanstvenih društev za zgodovino zdravstvene kulture Jugoslavije, Novo Mesto, 1981.

5. Jelić R.: Zdravstvo u Zadru i njegovom području, Zadar, 1978.

6. Jelić R.: Presjek kroz medicinsku prošlost Zadra, Acta hist. med. stom. pharm. vet., 21:1-2:11-42, 1981.

7. Gjivanović J.: Zdravstveni izvještaj Dalmacije za godine 1903., 1904. i 1905., Zadar, 1908.

8. DAZD (Državni arhiv u Zadru) (State Archives in Zadar): Spisi intendance za Dalmaciju (SID), Filza II, 516, 346-1813/1.

9. Manuale del Regno di Dalmazia per l'anno 1873., compilatio da Luigi Mascheck, anno III, Zara, 1873.

10. DAZD: Spisi Intendance za Dalmaciju(SID), Filza II, 516, 346, 1813/2.

11. Spomenica povodom stogodišnjice Babičke škole u Zadru, Zadar, 1951; Prilozi: Škarica M.: Primaljska škola u Zadru - historijski pregled; Zanella S.: Oko Zadarske babičke škole; Akerman R.: Pismeni ispit Ante Kuzmanića na natječaju za mjesto profesora Primaljske škole u Zadru god. 1832.; Artić A.: Suvremeni odgoj u Babičkoj školi; Rad Babičke škole u Zadru.

12. DAZD: Miscelanea, 114, P-1, 1-1.

13. DAZD: Miscelanea, 114, P-1, 1-13.

14. Jamnicki Dojmi M.: Zadarska primaljska škola od njezina osnutka 1820. do zatvaranja 1918. godine, Acta med-hist. Adriat. 2006;4 (1);129-152.

15. DAZD: Štampe austrijske vlade, br. 1437 d., str. 19, 1821.

16. Akerman R.: 150 godišnjica osnutka Škole za medicinske sestre primaljskog smjera u Zadru 1821-1971., Zadar, 1971.

17. DAZD: Miscelanea, 114, P-1, 1-21.

18. Gazzetta di Zara, 1848., 31.

19. Almanacco provinciale della Damazia, Zara, 1822, 1823, 1825, 1830, 1834.

20. DAZD: Štampe austrijske vlade, br. 144451/I, 901, 1822. 
21. DAZD: Miscelanea, 114, P-1, 1-77-80; 1-31-42; 1-174-178; 1-88-95; 1-284; 1-214; $1-215 ; 1-230 ; 1-216,219,220,223,224,225 ; 1-268 ; 1-49-95 ; 1-265 ; 1-334 ; 1-353,354$; $1-359 ; 1-67,70,73 ; 1-15 ; 1-20-23 ; 1-32-35 ; 1-38 ;$ P-2, 1-34; 125; P-5, 1-27; P-6, 1-63; P-7, 1-22; P-8, 1-61, 82, 99, 100; P-9, 1-13; P-10, 1-17; P-12, 1-23; P-13, 1-1,3,4,6,9,24,49.

22. Jelić R.: Zdravstveni radnici Dalmacije početkom XIX stoljeća, Jugoslav. akad. znan. i umet., Zagreb, 1989.

23. Škarica M.: Zadarski liječnici, Radovi Instituta JAZU u Zadru, knj. 2, Zagreb, 1955.

24. Gazzetta di Zara, 27.IX. 1835., 77.

25. Bazala V.: Povijest rodilišta u Hrvatskoj, Zbornik radova XII naučnog sastanka NDZIZKJ, str.210-220, Beograd, 1964.

26. Kulišić Š.: Ante Kuzmanić liječnik - ginekolog kao istaknuti kulturni i društveni radnik, Saopćenja, 2: 91-96, 1969.

27. Almanacco provinciale della Dalmazia, Zara, 1832.

28. Bulić I.: Splićanin Ante Kuzmanić (1803-1879), Novo doba, Split, god.21, br.90, 17.IV 1938.

29. Jamnicki Dojmi M.: 175 godina od početka rada Primaljske škole u Zadru, Zadar, 1996.

30. Pravdonoša, 1851., 2.

31. Avvisatore Dalmato - Objavitelj dalmatinski, 4, 1867.

32. Glasnik dalmatinski, Zadar, 1865., 20.

33. Zora dalmatinska, Zadar, 1844., 1.

34. Dugački V.: Zdravstvena problematika na stranicama "Zore dalmatinske“ i ličnosti glavnih urednika, liječnika mr Ante Kuzmanića i dr Ivana Kaznačića, Acta hist.med stom.pharm.vet.; 1-2:175-181, 1987.

35. Ante Kuzmanića Poslanica Dalmatincima, u Splitu, knjigopečatnja Oliveti i Giovannicio, 1861.

36. Kuzmanić A.: Braća Ante, Frane, Petar Ergovac, Ivan Petar Marki, braća Ante, Otavij, Ivan Petar Martiniš-Marki, Josip de Marki, Dobročinci splitski, Tiskarnica, braće Batara, Zadar, 1871.

37. DAZD: Štampe, Sv.55, br.80-a, 80-b.

38. Grmek M.D.: Inauguralne disertacije hrvatskih, srpskih i slovenačkih liječnika (1660-1865), Starine, 43, Zagreb, 1951.

39. Lalić N.: O važnosti primalje, Zadar, 1903.

40. Sirovica S.: Peričić dr Božo, Lalić dr Nikola (šibensko razdoblje djelovanja), Šibenik, 1989.

41. Grmek M.D.: Lalić Nikola, Med.enciklopedija, knj. 6: 311-312, Zagreb, 1962. 
42. Piskatscheck L.: Compendio di ostetricia per le allieve delle scuole di ostetricia e repertorio per le levatrici, Prima traduzione italiana sulla terza edizione tedesca del dott. Nicolo barone Lallich, Vienna, 1906.

43. Piskaček L.: Udžbenik za učenice primaljskog tečaja i priručna knjiga za primalje, po četvrtom nemačkom izdanju preveo dr Ante vitez Stermich, Zadar, 1911.

44. Škarica M.: Slovenec Andrija Mosetig in Babiška šola v Zadru, Zdravstveni vestnik, Ljubljana, 27:12:462-463,1958.

45. Gazzetta di Zara, 20.XII 1836., br 102.

46. Grmek M.D., Zmajić B.: Zagrepčan-protomedik Dalmacije i Mletaka (Život i rad dr Josipa Drčića), Liječ. Vjesn., 70:2-3:156, 1948.

47. Jelić R.: Osam liječnika iz Zadarske obitelji Pinelli, Radovi JAZU, Zadar 1979.

48. Gazzetta di Zara, 1847., br. 20.

49. Narodni list (Il nacionale), 1844., vol. 23, br. 69.

50. Gjivanović J.: O kužnim bolestima za općine i narod, Zagreb, 1890.

51. Sirovica S.: Epidemija kolere u Dalmaciji 1886., epidemija variole u Šibeniku 1887. i dr Karlo Vipauc, Šibenik, 1990.

52. Lamprecht R.: Manuale di ostetricia teorica e pratica per le allune levatrici, parte I, Coi tipi della Minerva, Padua, 1837; parte II, Coi tipi di Angelo Sicca, Padua, 1840 .

53. Bazala V.: Nekoliko podataka o medicini u Zadru, Alma mater Croatica, 7:510:159-162, 1970.

54. Kuzmanić A.: Šestdeset učenjah iz primaljstva za primalje, Zadar, 1875.

55. Bazala V.: Bibliografija naših babičkih udžbenika, Liječn. Vjesn., 55:11:590, 1933.

56. Lalich N.: Knjiga za primalje, Nagr. tisk. Petra Jankovića, Zadar, 1908. 


\section{SAŽETAK}

Primaljstvo je u Dalmaciji početkom XIX. stoljeća bilo veoma nerazvijeno. Prema zdravstvenom izvješću iz I8I3., u cijeloj je pokrajini bilo samo 48 primalja, a nijedna nije imala diplomu škole za primalje. Nakon ukidanja centralnih škola, ustanovljenih u vrijeme francuske vladavine, koje su imale rang sveučilišta, profesori koji su boravili u Zadru nastavili su svoj rad $i$ podučavanje $u$ Školi za primalje osnovanoj 1820 . u skladu sodlukom cara Franje I., koja je započela raditi I821. godine.

Budući da je škola radila bez prekida čitavo stoljeće, u njoj je predavalo više profesora, a protomedici Dalmacije po službenoj su dužnosti bili i ravnatelji Primaljske škole. U ovom je radu prikazan njihov život, radi doprinos medicini Dalmacije.

Iako nove učenice uglavnom nisu bile pismene, na raspolaganju su imale kvalitetne udžbenike. Neke od njih su napisali profesori Škole za primalje. Ovdje su analizirani udžbenici s aspekta današnje medicinske znanosti i prakse, što upućuje na njihovo značenje $i$ doprinos njihovih autora ugledu koji je škola uživala u to vrijeme.

Ključne riječi: Zadar; Dalmacija; Primaljska škola; udžbenici. 